\title{
Cognitive functions in children and adolescents with Multiple Sclerosis - preliminary studies
}

\section{Funkcje poznawcze u dzieci i młodzieży ze stwardnieniem rozsianym - badania wstępne}

\author{
Izabela Kaczmarek', Agnieszka Wencel-Warot' ${ }^{1}$, Karolina Kupczyk', Marcin Żarowski', \\ Wojciech Gorczyński², Barbara Steinborn ${ }^{1}$ \\ ${ }^{1}$ Chair and Department of Developmental Neurology, Poznan University of Medical Sciences, Poland \\ ${ }^{2}$ Adam Mickiewicz University, Poznan, Poland
}

\section{ABSTRACT}

Aim. The study of cognitive deficits in patients with multiple sclerosis is now regarded as the gold standard in the diagnosis and treatment of this disease. We present the first, so far, unpublished study of cognitive function in children and adolescents with multiple sclerosis (MS) to be undertaken in Poland Material and methods. The participants, 21 children and adolescents with multiple sclerosis (MS), were aged from 13 to 17 years old and were recruited among patients of the Department of Developmental Neurology, Poznan University of Medical Sciences. The study concerned some of the most studied cognitive processes in MS, ie. executive functions, auditory memory, manual tasks and logical thinking on non-verbal material. The results obtained in patients with MS were compared with the matched pairs of a control group. Results. The results show some differences in the course of cognitive processes (executive functions and manual skills) between the compared groups. At the same time the studies were able to reveal that 4 of the patients displayed a severe decline in the tested functions that required neuropsychological intervention. Conclusions. Due to the practical value of neuropsychological assessment in early course of the disease this procedure is intended for patients with MS

Key words: cognitive functions, multiple sclerosis, neuropsychology

\section{STRESZCZENIE}

Cel. Badanie procesów poznawczych u pacjentów ze stwardnieniem rozsianym, traktowane jest obecnie jako złoty standard w diagnostyce oraz leczeniu tej choroby. Prezentujemy pierwsze w Polsce dotychczas niepublikowane badania funkcji poznawczych u dzieci i młodzieży ze stwardnieniem rozsianym (SM). Materiał i metoda. 21 uczestników w wieku od 13 do 17 lat było rekrutowanych wśród pacjentów Kliniki Neurologii Rozwojowej Uniwersytetu Medycznego w Poznaniu. Badanie dotyczyło wybranych spośród najczęściej badanych procesów poznawczych w SM, tj. procesów wykonawczych, pamięci słuchowej, tempa zadań manualnych oraz umiejętności myślenia abstrakcyjno-logicznego na materiale niewerbalnym. Uzyskane wyniki w grupie pacjentów z SM porównano z dobraną parami grupą kontrolną. Wyniki. Wyniki badań wskazują na różnice w przebiegu wybranych procesów poznawczych (procesów wykonawczych oraz umiejętności tappingu) między porównywanymi grupami. Równocześnie przeprowadzone badania pozwoliły wyłonić 4 pacjentów z poważnymi obniżeniami w badanych funkcjach, które wymagały interwencji neuropsychologicznej. Wnioski. Ze względu na wartość utylitarną przeprowadzenie badania neuropsychologicznego we wczesnej fazie choroby jest procedurą dedykowaną dla pacjentów z SM.

Słowa kluczowe: funkcje poznawcze, stwardnienie rozsiane, neuropsychologia

\section{INTRODUCTION}

Impairment of cognitive functions and psychiatric disorders are, after mobility problems, one of the integral symptoms of Multiple Sclerosis (MS). According to the literature it is believed that 40 to $65 \%$ of patients experience cognitive impairment. Among the most frequently mentioned are: impaired memory and attention, reduction of visualspatial functions, slowed information processing speed and impaired executive functions (e.g. abstract and conceptual reasoning, fluency, planning and organization). The nature and severity of cognitive deficits depend on the following processes: inflammatory, demyelinating and neurodegenerative. Moreover, cognitive functioning in MS seems to be related to clinical variables like: Expanded Disability Status
Scale (EDSS), number of relapses, disease length, medication and course. Cognitive deficits (both types of problems and their severity) in each case is individual and occurs differently in patients, especially at the beginning of the disease. Impairment of cognitive functions may therefore manifest itself in extreme forms of dementia, in most cases, however, problems in patients are assessed as mild or of an average degree. Nevertheless, it should be noted that even a slight deterioration in cognitive functioning may significantly reduce the quality and functioning of the patient in daily life, especially if these impairments pertain to the processes of remembering, recalling or attention. 
Impairment of cognitive functions in patients with MS, especially at the beginning of the disease, usually relates to the domain - specific deficits, i.e. the impairment of one or two functions, which allows for the compensation of deficits by other, non-impaired cognitive skills. Most described profiles of impairment of cognitive functions indicate the so called subcortical profile of disturbance, although cortical deficits of cognitive deficits are also present. Primary cognitive function in MS are presented in tab. I.

Table I. Cognitive dysfunctions in MS patients Zaburzenia funkcji poznawczych u pacjentów z SM

\begin{tabular}{l} 
Memory disturbances - e.g. difficulties in memory of facts, \\
learning problems \\
\hline $\begin{array}{l}\text { Attention deficits - e.g. decline in attention and information- } \\
\text { processing speed }\end{array}$ \\
\hline $\begin{array}{l}\text { Executive function disturbance - e.g. difficulties in organizing, } \\
\text { planning and abstract thinking }\end{array}$ \\
\hline Visuospatial ability - e.g. difficulties in orientation of the "right"- \\
"left", reading maps, navigation in familiar and unfamiliar places \\
\hline Speech and language difficulties - e.g. verbal fluency decline, \\
speech problems
\end{tabular}

Despite extensive studies of cognitive functions in MS in adults and knowledge of the development of secondary dementia in the course of this disease, still relatively little is known about the impairment of cognitive functions and psychiatric symptoms in children and adolescents with MS and the course of these impairments during the disease and treatment.

At present, there is a renaissance in the studies of cognitive functions in patients with MS which began in the 1990's. Studies of impairment of cognitive functions in children and adolescent cases of MS were initiated by Kalb in 1999. Since then, there has also been a full acknowledgement of the recognition of cognitive impairment in children and adolescent forms of MS as one of many symptoms of the disease, rather than treating them as an effect of the patient's psychological reaction to the disease. Based on the available literature, we may conclude that the range of estimates of prevalence is various, ranging from 30 to well over 90, depending on the diagnostic criteria, methodologies, and patient population studied. The more stringent the methodological requirements (e.g. impairment of cognitive functions) are assessed in patients with impairments in at least 1 or 2 studied areas, the greater the percentage of cognitive impairments in the described groups of patients. An outline of the most important reports on the problem of cognitive functions in children and adolescents is shown in tab. II.

Table II. Reports on the problem of cognitive functions in children and adolescents with MS Przegląd badań dotyczących zaburzeń poznawczych u dzieci i młodzieży z SM

\begin{tabular}{|c|c|c|c|c|c|c|c|c|}
\hline Publication & Study type & $\mathbf{N}$ & $\begin{array}{l}\text { Mean } \\
\text { age }\end{array}$ & $\begin{array}{l}\text { EDSS } \\
\text { (min- } \\
\max )\end{array}$ & $\begin{array}{l}\text { Disease } \\
\text { duriation } \\
\text { (years) }\end{array}$ & $\begin{array}{l}\text { Cognitive } \\
\text { functions }\end{array}$ & $\begin{array}{l}\% \text { of patients } \\
\text { with } \\
\text { cognitive } \\
\text { impairment }\end{array}$ & Conclusions \\
\hline $\begin{array}{l}\text { Kalb, R.C. et } \\
\text { al., 1999, USA }\end{array}$ & $\begin{array}{l}\text { Series of } \\
\text { cases }\end{array}$ & 9 & $\begin{array}{l}16,69 \\
(2.60)\end{array}$ & $\begin{array}{l}3,11 \\
(0-8,5)\end{array}$ & & $\begin{array}{l}\text { Global intelligence, } \\
\text { memory, cognitive } \\
\text { flexibility, verbal } \\
\text { fluency }\end{array}$ & - & $\begin{array}{l}\text { High degree of } \\
\text { subject variability } \\
\text { on each of the } \\
\text { cognitive tests }\end{array}$ \\
\hline $\begin{array}{l}\text { McCann K.K. } \\
\text { at et al., 2004, } \\
\text { USA }\end{array}$ & Case study & 1 & 11,3 & - & 3 & $\begin{array}{l}\text { Intellectual, } \\
\text { adaptive and } \\
\text { academic } \\
\text { functioning, } \\
\text { language } \\
\text { functioning, } \\
\text { perceptual-motor } \\
\text { skills, memory and } \\
\text { attention, executive } \\
\text { functioning }\end{array}$ & - & $\begin{array}{l}\text { Low average } \\
\text { to borderline in } \\
\text { fine motor speed } \\
\text { and dexterity, } \\
\text { difficulties with } \\
\text { visual-motor } \\
\text { planning skills } \\
\text { depressive } \\
\text { symptoms and } \\
\text { fatigue }\end{array}$ \\
\hline $\begin{array}{l}\text { Banwell, B.L. } \\
\text { et al., 2004, } \\
\text { Canada }\end{array}$ & $\begin{array}{l}\text { Series of } \\
\text { cases }\end{array}$ & 10 & $\begin{array}{l}13,9 \\
(9,5- \\
17)\end{array}$ & $\begin{array}{l}0.85 \\
(0-1,5)\end{array}$ & $\begin{array}{l}3,8 \\
(0,7-7,9)\end{array}$ & $\begin{array}{l}\text { General intelligence, } \\
\text { expressive language } \\
\text { receptive language, } \\
\text { visuospatial, } \\
\text { motor, attention, } \\
\text { verbal and visual } \\
\text { memory, academic } \\
\text { functioning, } \\
\text { executive functions }\end{array}$ & $\begin{array}{l}100 \\
\text { (impairment } \\
\text { on at least one } \\
\text { test) }\end{array}$ & $\begin{array}{l}\text { Deficits in } \\
\text { executive } \\
\text { functions } \\
\text { processing speed } \\
\text { and working } \\
\text { memory }\end{array}$ \\
\hline
\end{tabular}




\begin{tabular}{|c|c|c|c|c|c|c|c|c|}
\hline Publication & Study type & $\mathbf{N}$ & $\begin{array}{l}\text { Mean } \\
\text { age }\end{array}$ & $\begin{array}{l}\text { EDSS } \\
\text { (min- } \\
\max )\end{array}$ & $\begin{array}{l}\text { Disease } \\
\text { duriation } \\
\text { (years) }\end{array}$ & $\begin{array}{l}\text { Cognitive } \\
\text { functions }\end{array}$ & $\begin{array}{l}\% \text { of patients } \\
\text { with } \\
\text { cognitive } \\
\text { impairment }\end{array}$ & Conclusions \\
\hline $\begin{array}{l}\text { MacAllister, } \\
\text { W.S., et al., } \\
2005 \text { National } \\
\text { Pediatric MS } \\
\text { Center, USA, }\end{array}$ & & 37 & $\begin{array}{l}14,86 \\
(8-17)\end{array}$ & $1,5(0-4)$ & $\begin{array}{l}1,5(0,1- \\
6,25)\end{array}$ & $\begin{array}{l}\text { Attention, language, } \\
\text { memory, visual- } \\
\text { spatial, and motor } \\
\text { functions }\end{array}$ & $\begin{array}{l}35 \text { (impaired } \\
\text { performance } \\
\text { on at least } \\
\text { two cognitive } \\
\text { tasks) }\end{array}$ & $\begin{array}{l}\text { Deficits in } \\
\text { complex } \\
\text { attention, verbal } \\
\text { fluency, verbal } \\
\text { memory and } \\
\text { visual memory }\end{array}$ \\
\hline $\begin{array}{l}\text { Amato, M.P.et } \\
\text { al., 2008, } \\
\text { Multiple } \\
\text { Sclerosis } \\
\text { Study Grou,p } \\
\text { of the Italian } \\
\text { Neurological } \\
\text { Society }\end{array}$ & $\begin{array}{l}\text { Case- } \\
\text { control }\end{array}$ & 63 & 15,3 & $\begin{array}{l}1,5 \\
(0-5,5)\end{array}$ & $\begin{array}{l}3(0,5- \\
15,5)\end{array}$ & $\begin{array}{l}\text { Global cognitive } \\
\text { functioning, verbal } \\
\text { and visuospatial } \\
\text { learning, sustained } \\
\text { attention, abstract } \\
\text { reasoning through } \\
\text { expressive } \\
\text { language, receptive } \\
\text { language }\end{array}$ & $\begin{array}{l}31 \text { (failure on } \\
\text { at least three } \\
\text { tests) } \\
53 \text { (failed } \\
\text { at least two } \\
\text { tests) }\end{array}$ & $\begin{array}{l}\text { Deficits } \\
\text { in memory, } \\
\text { complex } \\
\text { attention and } \\
\text { executive } \\
\text { functions }\end{array}$ \\
\hline $\begin{array}{l}\text { Till C.et al., } \\
\text { 2011, Canada }\end{array}$ & $\begin{array}{l}\text { Case- } \\
\text { control }\end{array}$ & 31 & $\begin{array}{l}16.36 \\
(S D= \\
2,36)\end{array}$ & $\begin{array}{l}\text { mediana } \\
1.0(0.0- \\
4.04)\end{array}$ & $\begin{array}{l}\text { mediana } \\
4,3 \\
(0.42- \\
13.3)\end{array}$ & $\begin{array}{l}\text { Global cognitive } \\
\text { functioning, } \\
\text { Attention and } \\
\text { processing speed, } \\
\text { Verbal memory, } \\
\text { visuoperceptual } \\
\text { ability, language, } \\
\text { executive functions }\end{array}$ & & $\begin{array}{l}\text { Reduction in } \\
\text { attention and } \\
\text { processing } \\
\text { speed, } \\
\text { visuomotor } \\
\text { integration, } \\
\text { and most aspects } \\
\text { of expressive } \\
\text { language }\end{array}$ \\
\hline $\begin{array}{l}\text { Julian L. et al., } \\
2013 \text { Network } \\
\text { of Pediatric } \\
\text { MS Centers of } \\
\text { Excellence }\end{array}$ & Cohort & 187 & $\begin{array}{l}14.8 \pm \\
2.6\end{array}$ & $\begin{array}{l}1.5 \\
(0-5.5)\end{array}$ & $2.2 \pm 2.3$ & $\begin{array}{l}\text { General ability } \\
\text { level, reading } \\
\text { and language, } \\
\text { attention, working } \\
\text { memory, speeded } \\
\text { processing, } \\
\text { executive } \\
\text { functioning, } \\
\text { verbal episodic } \\
\text { learning and } \\
\text { recall, visuospatial } \\
\text { functioning, fine } \\
\text { motor speed and } \\
\text { coordination }\end{array}$ & $\begin{array}{l}35 \text { (mild } \\
\text { impairment } \\
\text { score }<1 \\
\text { SD below the } \\
\text { normative } \\
\text { mean, } \\
\text { moderate } \\
\text { impairment } \\
\text { scores }<2 \\
\text { SD below } \\
\text { population } \\
\text { norms) }\end{array}$ & $\begin{array}{l}\text { Impairment in } \\
\text { fine motor speed } \\
\text { and coordination, } \\
\text { speeded } \\
\text { processing }\end{array}$ \\
\hline $\begin{array}{l}\text { Charvet LE. } \\
\text { et al., 2014, } \\
\text { US Pediatric } \\
\text { Multiple } \\
\text { Sclerosis } \\
\text { Network. }\end{array}$ & $\begin{array}{l}\text { Cohort } \\
\text { longitudinal } \\
\text { evaluation }\end{array}$ & $\begin{array}{l}67 \\
(62 \\
\text { MS, } \\
5 \\
\text { CIS) }\end{array}$ & $\begin{array}{l}12.89 \\
\pm 3.13\end{array}$ & $\begin{array}{l}1.25 \\
(0-3.5)\end{array}$ & $\begin{array}{l}1.56 \pm \\
1.93\end{array}$ & $\begin{array}{l}\text { General intellect, } \\
\text { attention and } \\
\text { working memory, } \\
\text { verbal memory, } \\
\text { visuomotor } \\
\text { integration, } \\
\text { language, } \\
\text { and executive } \\
\text { functioning }\end{array}$ & $\begin{array}{l}37.3 \% \text { having } \\
\text { one -third } \\
\text { or more test } \\
\text { scores in } \\
\text { the impaired } \\
\text { range }\end{array}$ & $\begin{array}{l}\text { Lowest } \\
\text { performances in } \\
\text { visuomotor } \\
\text { integration, } \\
\text { verbal recall and } \\
\text { attention }\end{array}$ \\
\hline
\end{tabular}

\section{MATERIALS AND METHODS}

\section{Participants}

The aim of the study was to compare selected cognitive skills in patients with MS and healthy children, aged 13 to 17 years.

All the patients were diagnosed with relapsing - remitting Multiple Sclerosis according to the 2010 Revised Mc
Donald criteria. Optic neuritis, sensory symptoms, hemi or monoparesis and brain-stem related syndromes were the most frequently occurring symptoms of the first relapse. In most cases (15) the onset of the disease was monofocal and in 6 cases was multifocal. Neurological examinations and the EDSS were performed by a board-certified neurologist. At the time of neuropsychological evaluation all the patients were relapse free. To compare neuropsychological 
performance, a group of demographically matched healthy controls was also assessed. 21 healthy subjects were matched in accordance with age, sex and years of education to the patients. The controls were free of neurological or psychiatric disease. The presented study was approved by the ethics committee of the University of Medical Sciences, Poznan. In the examined group of patients, none had previously been diagnosed with mental retardation. A detailed description of the study group is listed in tab. III. of 30 pairs of rhythms generated by the computer in three series, 10 pairs in each of the series. In the first series the presented pairs contain 5 musical notes each, in the second series, they contain 6 musical notes each; the third series is the longest and contains 7 notes in each trial. The task of the participant is to compare each of these pairs and make a decision on whether the presented pairs are the same or different. The duration of each musical note is $70 \mathrm{~ms}$, the pitch of the tone is $500 \mathrm{~Hz}$ and the interval between the

Table III. Descriptive statistics for MS patients and controls Statystyki opisowe dla pacjentów z SM oraz grupy kontrolnej

\begin{tabular}{|c|c|c|}
\hline & Patients ( $\mathrm{n}=21$ ) & Healthy controls $(n=21)$ \\
\hline Sex - female/male & $16 / 5$ & $16 / 5$ \\
\hline Age - mean, SD (range), [max-min.] y & $\begin{array}{l}16,1(\mathrm{SD}=1,48)[\min .13-\max \\
17]\end{array}$ & $\begin{array}{l}15,7(S D=1,51) \\
{[\min .13-\max 17]}\end{array}$ \\
\hline Education - mean, [max-min.] y & $9,5[\min .6-\max 12]$ & $9,2[\min .6-\max 12]$ \\
\hline Age at onset, mean SD (range), [max-min.] y & $14,8[\min .9-\max 17]$ & - \\
\hline Disease course & relapsing-remitting & - \\
\hline EDSS score - mean [max-min.] & $1[\min .0-\max 1,5]$ & - \\
\hline $\begin{array}{l}\text { MS duration (since symptom } \\
\text { onset to assessment) - mean SD [max-min.], mo }\end{array}$ & $15,71(14,99)[\min .2-\max 36]$ & - \\
\hline No. of relapses [max-min.] & $2,55[\min .1-\max 6]$ & - \\
\hline
\end{tabular}

\section{Neurospychological assessment}

The study of cognitive functions is now regarded as one of the most fundamental in group of MS patients. To assess the cognitive functions of the young MS patients a variety of tasks and tests were selected: for abstract reasoning - Raven's Matrices Test, for assessment of executive functionsClassification Task, for auditory memory - Rhythm Task and for assessment of manual abilities (including fatigue) - Finger Tapping Task.

1. Raven's Matrices Test. For measurement of fluid intelligence the Standard Version of, Raven's Matrices test (frequently applied in screening tests) was used. It is a nonverbal test which measures the ability of logical thinking, independent of the individual's experience. The test book contains 5 sets of 12 tasks. Each task consists of a selection of one of several elements that matches the pattern (matrix). The test result is a converted percentile outcome in relation to age standards.

2. The Finger Tapping Task - a psychomotor speed test used for the testing of psychomotor ability to perform quick hand movements. In studies of patients with MS, the tapping test is a commonly used tool to assess fatigue.

In this task, the patient is asked to tap the spacebar as quickly as possible, alternatively, once with a right and once with a left index finger. Tapping is performed alternately in 10 trials ( 5 trials for each hand). The measurement time for each trial is 10 seconds. The test result is the sum of taps performed during 5 trials for the dominant and non-dominant hand.

3. Rhythm task: this is a computer version of the Sheasore test. It consists of a presentation and comparison pairs is 1 second. The standard rhythmic pattern formed of 5 musical notes is $1475 \mathrm{~ms}$ in the first series, in the second series it is $2005 \mathrm{~ms}$, and from the third series it is $2595 \mathrm{~ms}$. The result of the test is the number of correct comparisons. The test is used for the measurement of analysis and auditory memory.

4. Classification Task - the classification test is based on a task switching paradigm and is used for studying executive and attentional processes as well as plasticity of thinking. The basis for the construction of this task is the popular Wisconsin Card Sorting Test.

The task of the participant is to put 128 test cards on the stimulus cards located at the top of the monitor, according to the established three possible sorting rules, which are: card colour, the shape of the stimulus or the number of stimuli on each test card. The sorting criterion is selected by the computer, and the participant receives a feedback if the test cards are correctly matched to the stimulus cards. The feedback is given in the form of answer: ,good” or „wrong" which appears at the bottom of the screen. After 9 subsequent correct matches, the computer changes the rule which must be recognized again by the participant. The test results are defined as: the number of correctly matched categories (Cat), the number of correct answers (C), the sum of all committed errors (E), the number of so-called perseverative errors $(\mathrm{PE})$ and the number of non-perseverative errors (NPE).

For the statistical calculation of the obtained results used was non-parametric U Mann-Withney test in Graphpad program. 


\section{RESULIS}

Raven Matrices Test, standard version. In the screening test using the Raven Matrices Test, all examined patients obtained a result corresponding to the age standard, i.e. they obtained the result converted in the range of 25 to 75 centiles, and the average test result was 66.75 centiles.

Tapping. In the tapping test, the average result for the dominant hand in the group of patients with MS was $63,91(\mathrm{SD}=7,08)$ and was lower than the result obtained by healthy persons, which was 65,16 , $(\mathrm{SD}=4,85)$. Differences in the execution of the task were not statistically significant (U-Test: $\mathrm{Z}=-0.5351, \mathrm{p}=0.589$ ). For the nondominant hand, the average obtained result in the group of ill persons was 55,78 $(\mathrm{SD}=5,97)$ and in the control group it was $58,03(\mathrm{SD}=6,04)$. There was no statistically significant difference in the execution of the task between the two studied groups (U-Test: $Z=-0.0675, p=0.944$ ). The sum of the average results obtained in the studied groups is presented in Diagram 1.
Analysis of individual trials of the tapping test which allows for recognition of slowdown and fatigability in performing manual activities, indicates the presence of a statistically significant difference in the execution of the task between the studied groups in the second trial of the test for the non-dominant hand. In this task, those with MS obtained a lower result $(55,31, \mathrm{SD}=5,92)$ than the control group $(59, \mathrm{SD}=5,15) \mathrm{p}<0,05$. The result for ten individual tapping trials is presented in tab. IV.

Rhythm task. In the rhythm comparison test, a higher score was obtained by the healthy group (average of correct comparisons $=26,06, \mathrm{SD}=2,51$ ) compared with the results of patients with MS (average of correct comparisons $=24,38, \mathrm{SD}=4,97)$. The U-Mann test, however, did not show a statistically significant difference in the execution of this task between the compared groups (U-test: $\mathrm{Z}=$ $0.2341, p=0,818)$. Graphical representation of the results is shown in Diagram 2.

Diagram 1. Results of the tapping test for the dominant and non-dominant hand in patients with MS and for the control group Wyniki testu tappingu dla ręki dominującej i niedominującej w grupie pacjentów z SM i w grupie kontrolnej
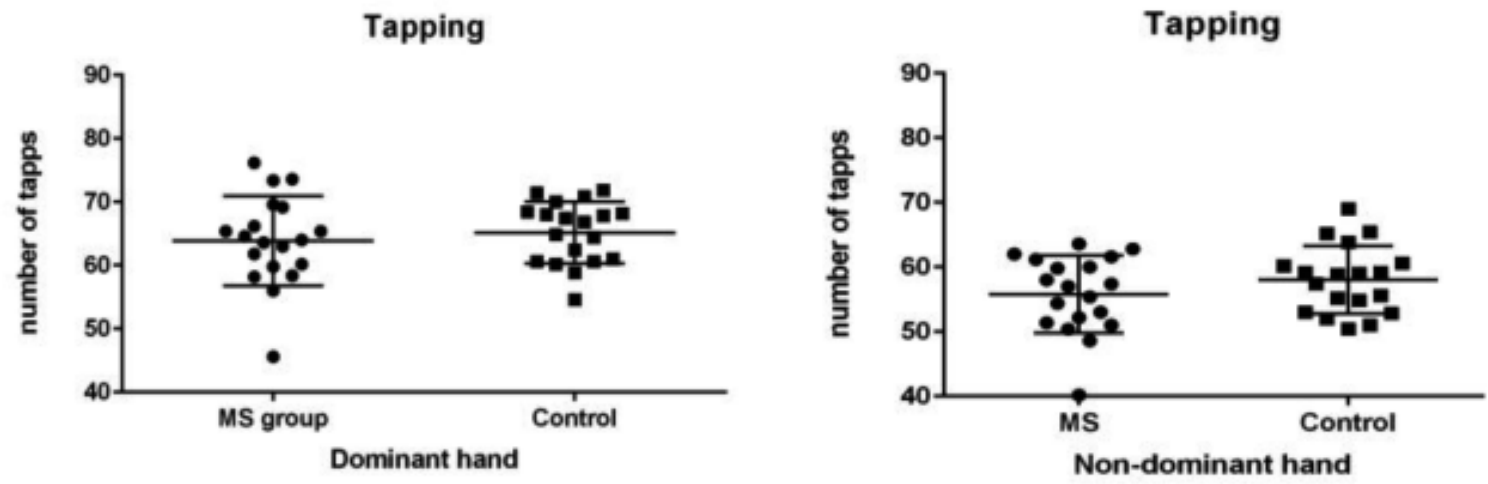

Table IV. Results of U Whitney-Mann test for 10 trials of tapping for domimant and non-dominant hand patients with MS and for control group Wyniki statystyki U Whitneya-Manna dla 10 prób testu tappingu dla ręki dominującej i niedominującej u pacjentów z SM oraz grupy kontrolnej

\begin{tabular}{lllllll}
\hline & No & $\begin{array}{l}\text { Mean } \\
\text { MS group }\end{array}$ & SD & $\begin{array}{l}\text { Mean } \\
\text { Healthy group }\end{array}$ & SD & P value \\
\hline Dominant hand 1 & 20 & 65,31 & 9,069 & 67,36 & 5,955 &, 272 \\
\hline Dominant hand 2 & 20 & 64,73 & 8,420 & 64,94 & 6,140 &, 948 \\
\hline Dominant hand 3 & 20 & 63,52 & 7,749 & 64,73 & 6,245 &, 638 \\
\hline Dominant hand 4 & 20 & 62,94 & 7,971 & 64,63 & 6,426 &, 413 \\
\hline Dominant hand 5 & 20 & 63 & 7,893 & 64,10 & 5,860 &, 537 \\
\hline Non-domimant hand 1 & 20 & 58,31 & 8,890 & 60,73 & 6,703 &, 219 \\
\hline Non-dominant hand 2 & 20 & 55,31 & 5,926 & 59 & 5,157 &, $045^{* *}$ \\
\hline Non-dominant hand 3 & 20 & 55,31 & 8,363 & 57,73 & 6,677 &, 364 \\
\hline Non-dominant hand 4 & 20 & 55,10 & 7,782 & 55,73 & 6,340 &, 982 \\
\hline Non-dominant hand 5 & 20 & 54,94 & 7,736 & 56,94 & 6,069 &, 464 \\
\hline
\end{tabular}

SD - standard deviation; ${ }^{* *}$ - statistically significant. 
Diagram 2. Results of the test of comparison of the average recognitions of rhythm among patients with MS and from the control group Wyniki porównawcze średniej rozpoznawania rytmów między pacjentami z SM i grupą kontrolną

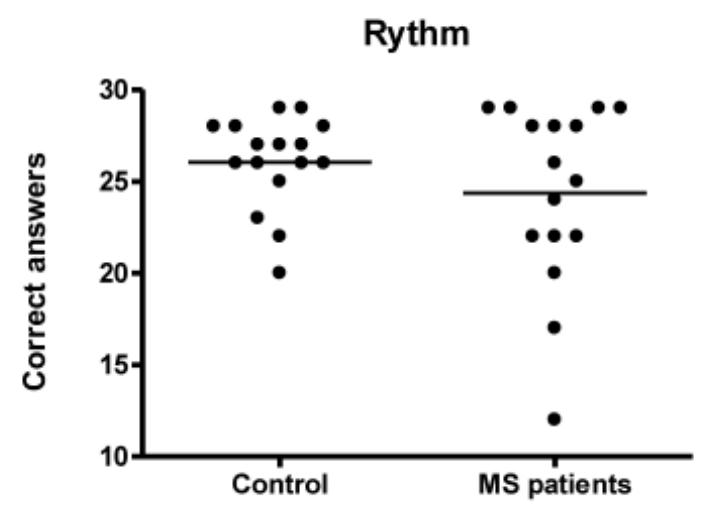

Classification Task. The assessment of the Classification Task test took into account: the number of correct answers $(\mathrm{C})$, the number of committed perseverative errors (PE) which are considered the equivalent of executive functions, the number of non-perseverative errors $(E)$ associated with attentional processes and the number of correctly matched categories (Cat). Comparisons showed significant statistical differences in the performance of the test between both studied groups within the scope of the number of the committed perseverative errors. Those with MS committed the largest number of errors in this test (see tab. V).

\section{CORRELATION ANALYSIS}

In the clinical group of patients with MS, an analysis was carried out of the correlation between the obtained results of the conducted tests and clinical parameters: EDSS, duration of symptoms up to neuropsychological assessment and the number of relapses.

The results of the r-Spearman correlation indicate a strong negative correlation between the outcome in the tapping test for dominant and non-dominant hand for all clinical parameters; in the tapping of the left hand there is a strong negative correlation between the duration of symptoms and a moderate correlation between the number of relapses of the disease and the manner of performance of the test.

A study of the correlation for the classification test also indicated the existence of a connection between the number of relapses, the number of perseverative errors and the number of categories matched in the test. The results of the correlation analysis are shown in tab. VI.

Table V. Results of classification tests for patients with MS and for control group Wyniki testu klasyfikacji dla pacjentów z SM i grupy kontrolnej

\begin{tabular}{llllllll}
\hline & N & MS group & SD & $\begin{array}{l}\text { Control } \\
\text { group }\end{array}$ & SD & $\begin{array}{l}\text { U-test } \\
\text { Z }=\end{array}$ & P value \\
\hline $\mathrm{E}$ & 21 & 16,53 & 14,323 & 15,89 & 15,552 & 0.2887 & $0.771 \mathrm{~ns}$ \\
\hline $\mathrm{C}$ & 21 & 14,95 & 17,656 & 14,05 & 13,713 & 0.2485 & $0.802 \mathrm{~ns}$ \\
\hline PE & 21 & 8,53 & 10,351 & 5,89 & 8,259 & 1.0525 & $0.048^{* *}$ \\
\hline NPE & 21 & 6,42 & 3,878 & 7,32 & 5,355 & 0.3947 & $0,689 \mathrm{~ns}$ \\
\hline
\end{tabular}

E - errors; C - correct answers; PE - perseverative errors; NPE - non-perseverative errors; ${ }^{*}$ - statistically significant ( $p<$ $0,05)$; ns - not statistically significant in U-Mann Test.

Table VI. Results of the correlation between the results of cognitive tests and the results of the EDSS, the number of relapses and disease duration Wyniki korelacji między wynikami testów poznawczych i wyników EDSS, liczby rzutów oraz czasu trwania choroby

\begin{tabular}{llll}
\hline Neuropschological test & EDSS, $r$ & No of relapses, $r$ & Disease duration, $r$ \\
\hline Tapping P & $-.73, p=0,0002^{* *}$ & $-.60, p=0.005^{* *}$ & $-.68, p=0.0008^{* *}$ \\
\hline Tapping L & $-.28, p=0,215$ & $-.55, p=0.011^{* *}$ & $-.72, p=0.00033^{* *}$ \\
\hline Rhythm & $-.02, p=0,516$ & $-.16, p=0.247$ & $-.21, p=0.413$ \\
\hline Cat- E & $.25, p=0,292$ & $.49, p=0,030$ & $.31, p=0,187$ \\
\hline Cat-C & $.16, p=0,486$ & $.42, p=0,069$ & $.43, p=0,062$ \\
\hline Cat-PE & $.24, p=0,315$ & $.45, p=0,042^{* *}$ & $.21, p=0,366$ \\
\hline Cat-NPE & $.03, p=0,875$ & $.35, p=0,132$ & $.17, p=0,462$ \\
\hline Cat - numer cards & $.20, p=0,390$ & $.44, p=0,041^{* *}$ & $.22, p=0,337$ \\
\hline
\end{tabular}




\section{DISCUSSION}

The study of cognitive functions during the initial stage of multiple sclerosis allows any possible deficits at this phase of the disease to be determined. Thanks to this, among other things, it is possible to commence therapeutic activities in sufferers who experience a lowering of cognitive processes. It is also important to monitor the course of cognitive functioning throughout the disease and its pharmacological treatment.

Frequency of the occurrence of cognitive impairment. Assuming, according to Amato, that the criterion of recognizing cognition impairment is the occurrence of deficits (results below 1,5 SD in comparison with the normative results) in at least 2 studied functions, 8 patients in the group of 21 patients in our study would meet these criteria. This constitutes $38,09 \%$ of all studied patients. If, as a critical point it is assumed that there are 3 incorrect results in the examined cognitive areas, the criteria of serious cognitive impairment would be met by 4 patients, which amounts to $19,04 \%$.

The presented results comparing the group of 21 patients with juvenile multiple sclerosis and healthy peers indicate the presence of statistically significant differences in individual clinical trials that concern the rate of performance of manual tasks (tapping test) and executive processes (perseverative errors in the classification test).

Studies of executive functions are one of the most frequently used tools in cognitive studies of patients with neurodegenerative diseases. The results presented in our studies, using classification tests, indicate a decline in the efficiency of execution of tasks that require the inhibition of a previously learned reaction in the group of patients with MS. With regard to the juvenile forms of MS, the studies of Amato et al. and Julian et al. have suggested that executive functions are impaired. However, the significant difference in the results obtained between the described groups presented in the studies of Amato et al. may be due to the clinical criteria of selection for groups, among which were patients whose level of intelligence was below normal for age, with mental retardation, much higher EDSS, i.e. 5,5 and a longer period of disease (from 0,5 to 15,4 years). When testing cognitive functions, the selection of a homogeneous group is extremely difficult and the introduction of people with mental retardation to the described group may distort (in this case lower) the results which may be attributed to the rest of the group. The group of patients described by Julian was considerably more homogeneous and therefore more suitable for selection to a clinical group, although the results in the EDSS scale $(0-5,5)$ may indicate the presence of patients with significant deterioration in the area of mobility, which would, no doubt, affect their performance in cognitive tests. Other results indicating the impairment of executive functions during the early stage of the disease were also obtained by Schulz et al. in The Madrid card sorting test which corresponds to the sorting test used in executive function studies, in a studied group of 21 patients with a similar duration of the disease (average of 15 months). However, the age of the group studied by Schulz was significantly higher, averaging 37 years. Impairment of executive functions is also indicated by the findings of Santiago et al. however, although the author talks about an early stage of the disease, the results presented relate to patients with an average disease length of 10 years.

The slight difference in our results obtained for the tapping test may be explained by the lack of clinical parameters for manual disorders in patients, such as trembling and dysmetria, which significantly determine the occurrence of disorders, e.g. in the rate of performing manual tasks. Studies indicating significant differences in the results of tests for fatigue and the rate for carrying out manual tasks usually relate to adults (see works: Chipchase et al., Alusi et al. and Bergendal et al.).

Other results, although not showing statistically significant differences, do indicate a certain trend; healthy persons obtained higher results in all the performed tests in comparison with the group of ill persons. However, differences between the groups do not meet the parametric criteria that would allow a rejection of the hypothesis of a lack of significant difference in the course of other studied tests between the described groups.

The applied correlation tests indicate a connection between the clinical parameters (in the form of results of the EDSS scale, duration of the disease and the number of relapses) and the results of the tapping test in the studied group of patients. A similar correlation exists between the number of relapses and the number of committed perseverative errors and the amount of matched categories in the classification test. In the case of the juvenile form of MS, the relations between the execution of cognitive tasks and the EDSS scale and the number of relapses are presented, among others, in works of MacAllister et al., although in some works, these relations are not indicated.

The presented studies have, above all, a significant practical value as they indicated a group of 8 patients, $38 \%$ of the group, whose cognitive functions were shown to be impaired. For these patients it was necessary to introduce measures aimed at a rehabilitation of lowered functions.

These studies leave no doubt as to the need to examine cognitive processes from the moment of recognition and introduction of pharmacological treatment and are in line, among others, with the recommendations of Rogers and Panegyres. Increased recognition of pediatric multiple sclerosis in recent years has led to an improved understanding of the clinical features of multiple sclerosis in children. It is crucial to understand that children are not small adults. Maturation and plasticity of neural networks in childhood and adolescence is fundamentally different from the connectivity of neural networks in the adult patient with multiple sclerosis. Early detection of cognitive impairment in children and adolescents allows for a quick therapeutic intervention that would prevent deepening of deficits and improve the daily functioning of the patient, as it is the optimum cognitive functioning that largely guarantees the independence of the patient in this difficult disease. Future research should include an evaluation of the effect of the disease-modifying agents on neurocognitive performance in children and adolescents with multiple sclerosis so as 
to assess potential neuroprotective strategies for all young patients with multiple sclerosis. The potential implications of such studies for intervention strategies in children with

\section{REFERENCES}

[1] Winkelmann A., Engel C., Apel A., et al.: Cognitive impairment in multiple sclerosis. J Neurol 2007; 254 Suppl 2: II35-42.

[2] Rogers J.M., Panegyres P.K.: Cognitive impairment in multiple sclerosis: evidence-based analysis and recommendations. J Clin Neurosci 2007 14: 919-927.

[3] Stoquart-Elsankari S., Perin B., Lehmann P., et al.: Cognitive forms of multiple sclerosis: report of a dementia case. Clin Neurol Neurosurg 2010; 112: 258-260.

[4] Karlinska I., Selmaj K.: [Cognitive impairment in multiple sclerosis]. Neurol Neurochir Pol 2005; 39: 125-133.

[5] McCann K.K., Farmer J.E., Patel N.: Childhood-onset multiple sclerosis and mood disorders: a case study. Child Neuropsychol 2004; 10: 102116.

[6] Banwell B.L.: Pediatric multiple sclerosis. Curr Neurol Neurosci Rep 2004; 4: 245-252.

[7] MacAllister W.S., Belman A.L., Milazzo M., et al.: Cognitive functioning in children and adolescents with multiple sclerosis. Neurology 2005; 64 : 1422-1425.

[8] Amato M.P., Goretti B., Ghezzi A., et al.: Cognitive and psychosocial features of childhood and juvenile MS. Neurology 2008; 70: 1891-1897.

[9] Till C., Ghassemi R., Aubert-Broche B., et al.: MRI correlates of cognitive impairment in childhood-onset multiple sclerosis. Neuropsychology 2011; 25: 319-332.

[10] Julian L., Serafin D., Charvet L., et al.: Cognitive impairment occurs in children and adolescents with multiple sclerosis: results from a United States network. J Child Neurol 2013; 28: 102-107. multiple sclerosis addressed to improve clinical and neurocognitive outcomes cannot be overlooked.

[11] Charvet L.E., O'Donnell E.H., Belman A.L., et al.: Longitudinal evaluation of cognitive functioning in pediatric multiple sclerosis: report from the US Pediatric Multiple Sclerosis Network. Mult Scler 2014; 20: 1502 1510.

[12] Chipchase S.Y., Lincoln N.B., Radford K.A.: Measuring fatigue in people with multiple sclerosis. Disabil Rehabil 2003; 25: 778-784.

[13] Alpherts W.C., Vermeulen J., Franken M.L., et al.: Lateralization of auditory rhythm length in temporal lobe lesions. Brain Cogn 2002; 49: 114-122.

[14] Nyhus E., Barcelo F.: The Wisconsin Card Sorting Test and the cognitive assessment of prefrontal executive functions: a critical update. Brain Cogn 2009; 71: 437-451.

[15] Schulz D., Kopp B., Kunkel A., et al.: Cognition in the early stage of multiple sclerosis. J Neurol 2006; 253: 1002-1010.

[16] Santiago 0., Guardia J., Casado V., et al.: Specificity of frontal dysfunctions in relapsing-remitting multiple sclerosis. Arch Clin Neuropsychol 2007; 22: 623-629.

[17] Alusi S.H., Glickman S., Patel N., et al.: Target board test for the quantification of ataxia in tremulous patients. Clin Rehabil 2003; 17: 140-149.

[18] Bergendal G., Martola J., Stawiarz L., et al.: Callosal atrophy in multiple sclerosis is related to cognitive speed. Acta Neurol Scand 2013; 127: 281-289.

[19] Banwell B.L., Anderson P.E.: The cognitive burden of multiple sclerosis in children. Neurology 2005; 64: 891-894.

\section{Adres do korespondencji:}

Izabela Kaczmarek, Oddział Neurologii Dzieci i Młodzieży, Szpital Kliniczny, Ul. Przybyszewskiego 49, 60-355 Poznań, tel.: 604944611 ;

e-mail: isab@poczta.onet.pl 